\title{
EVALUATION OF SURGE, ALTERNATIVE AND CONTINUOUS FLOW IN FURROW IRRIGATION WITH COTTON CROP AT NORTH DELTA. \\ El-Hadidi, E. M. ${ }^{\star}$; M. M. Saied ${ }^{\star \star}$ and M.A. E.M. Aiad ${ }^{\star \star}$ \\ * Soil Science, Fac. Agric. Mansoura university \\ ${ }^{\star *}$ Soils, Water and Environment Res. Inst., Agric. Res. Center Egypt.
}

\begin{abstract}
The objective of evaluating surface irrigation systems is to identify management practices and system configurations that can be feasibly and effectively implemented to improve the irrigation efficiency.

Two field experiments were conducted at Sakha Agricultural Research Station, Kafr Elshiekh Governorate during two successive summer seasons (2006 and 2007) to study the evaluation of surge, alternative and continuous flow in furrow irrigation with cotton crop. A randomized complete block design with four replicates was used and the irrigation treatments were as follows; surge flow with cycle ratio 0.5 ( 5 min. on and $5 \mathrm{~min}$. off or $10 \mathrm{~min}$. on and $10 \mathrm{~min}$. off), surge flow with cycle ratio 0.66 (10 $\mathrm{min}$. on and $5 \mathrm{~min}$. off or $20 \mathrm{~min}$. on and $10 \mathrm{~min}$. off), surge flow with cycle ratio 0.75 (15 min. on and $5 \mathrm{~min}$. off or $30 \mathrm{~min}$. on and $10 \mathrm{~min}$. off), alternative furrow irrigation and continuous flow.

The results indicated that the performance of the system during the evaluation was acceptable in case of surge flow at 0.75 cycle ratio with $30 \mathrm{~min}$. on and $10 \mathrm{~min}$. off in the two growing seasons. In case of continuous flow, the performance of the system was poor since about 48 percent of all water applied was lost from the field as runoff or deep percolation.

Keywords: surge, irrigation, alternative, furrow, continuous flow, clay soil.
\end{abstract}

\section{INTRODUCTION}

Irrigation water management is very important in Egypt due to shortage in water resources as well as the expansion of agriculture in newly reclaimed lands. Water supply in Egypt is limited to the average annual share of the Nile water at Aswan $\left(55.5 \times 10^{9} \mathrm{~m}^{3}\right)$ plus some minor quantities of ground water and rainfall. Much water is wasted and the irrigation efficiency is very low. Many studies were carried out to improve irrigation efficiencies to achieve the proper economic use of water. Surge flow and alternative furrow irrigation are the main factors affecting directly the irrigation efficiencies of surface irrigation system.

Many authors and investigators .i.e. Stringham and Keller (1979), Bishop et al. (1981), Ismail et al. (1985), Ghalleb (1987), Allen (1980), Osman (1991), Osman et al. (1996), Eid, (1998) and Aiad (2003) stated that surge flow system seemed to be more efficient than continuous irrigation because of less runoff, less deep percolation and less opportunity for leaching of nutrients.

Also, Meleha (2000) showed that the water requirements for cotton plants ranged between 3500 and $3638 \mathrm{~m}^{3} /$ feddan.

El-Shahawy (2004) found that the irrigation of all furrows under traditional land levelling received the highest amount of irrigation water. On the other 
hand, alternative furrow irrigation under precision land levelling received less amount of irrigation water.

Design and evaluation procedures for surface irrigation typically focus on the hydraulic of the water flow, assuming everything else is uniform (Merriam and Keller 1978).

The objective of this study was to evaluate surge irrigation at different cycle ratios, alternative furrow irrigation and continuous flow irrigation with cotton crop at North Delta.

\section{MATERIALS AND METHODS}

Two field experiments were conducted at Sakha Agricultural Research Station, Kafr El-Shiekh Governorate during two successive summer seasons of 2006 and 2007 . The station is situated at $31^{\circ} 07^{-} \mathrm{N}$ latitude, $30^{\circ} 57^{-} \mathrm{E}$ longitude. It has an elevation of about 6 meters above the sea level.

Some physical and chemical properties of the soils of the experimental field were determined according to standard methods (Black, 1965 and Garcia, 1979), and are shown in Table (1).

Table (1): Some soil chemical and physical properties of the experimental field.

\begin{tabular}{|c|c|c|c|c|c|c|c|c|c|c|}
\hline \multirow{2}{*}{$\begin{array}{l}\text { Depth } \\
\text { (cm) }\end{array}$} & \multirow{2}{*}{$\begin{array}{c}{ }^{*} \mathrm{pH} \\
1: 2.5\end{array}$} & \multirow{2}{*}{$\begin{array}{c}{ }^{\star \star} E C \\
d S / m \\
\text { at } \\
25^{\circ} \mathrm{C}\end{array}$} & \multicolumn{3}{|c|}{$\begin{array}{l}\text { Particle size } \\
\text { distribution }\end{array}$} & \multirow{2}{*}{$\begin{array}{c}\text { Texture } \\
\text { class }\end{array}$} & \multicolumn{3}{|c|}{$\begin{array}{c}\text { Soil moisture } \\
\text { characteristics }\end{array}$} & \multirow{2}{*}{$\begin{array}{c}\text { Bulk } \\
\text { density } \\
\text { g/cm }\end{array}$} \\
\hline & & & $\begin{array}{c}\text { Sand } \\
\%\end{array}$ & $\begin{array}{c}\text { Silt } \\
\%\end{array}$ & \begin{tabular}{c|} 
Clay \\
$\%$
\end{tabular} & & $\begin{array}{c}\text { F.C. } \\
\%\end{array}$ & P.W.P. & A.W. & \\
\hline \multicolumn{11}{|c|}{ First season } \\
\hline $0-1$ & 7.93 & 69 & 16.56 & 23.00 & 60.44 & Clay & 42.20 & 1.85 & 20.35 & 16 \\
\hline $15-3$ & 8.35 & 1.78 & 17.57 & \begin{tabular}{|l|}
25.07 \\
\end{tabular} & 57.36 & & 39.60 & & 18.62 & \\
\hline 30 & 8.40 & 2.93 & 18.74 & 20.52 & 60.74 & & 38.44 & 39 & 17.55 & 3 \\
\hline-60 & 8.82 & 3.87 & 18.28 & 24.88 & 56.84 & (1) & 37.40 & .33 & 17.07 & 1.3 \\
\hline \multicolumn{11}{|c|}{ Second season } \\
\hline & 8.26 & 2.22 & 7.14 & 23.90 & 58.96 & Clay & 44.50 & 52 & 21.98 & 12 \\
\hline 15 & 8.64 & 2.63 & 18.86 & 24.40 & 56.74 & C & 41.10 & 20.65 & 20.45 & 1 \\
\hline $30-45$ & 8.69 & 2.96 & 15.99 & 24.12 & 59.89 & $\mathrm{Cla}$ & 38.90 & 20.10 & 18.80 & .31 \\
\hline $5-60$ & 8.77 & 3.70 & 17.16 & 20.89 & 61.95 & Clay & 38.15 & 19.80 & 18.35 & 1.34 \\
\hline
\end{tabular}

A randomized complete block design with four replicates was used. The irrigation treatments were as follows:

- Surge flow with cycle ratio 0.5 (5 min. on and $5 \mathrm{~min}$. off)

- Surge flow with cycle ratio 0.5 (10 min. on and $10 \mathrm{~min}$. off)

- Surge flow with cycle ratio 0.66 (10 min. on and $5 \mathrm{~min}$. off)

- Surge flow with cycle ratio 0.66 (20 min. on and $10 \mathrm{~min}$. off)

- Surge flow with cycle ratio 0.75 (15 min. on and $5 \mathrm{~min}$. off)

- Surge flow with cycle ratio 0.75 (30 min. on and $10 \mathrm{~min}$. off)

- Alternative furrow irrigation

- Continuous flow (control) 
Egyptian cotton (Gossypium barbadenese L.) variety Giza 89 was planted. All agricultural operations were performed according to the usual local agricultural management of the MALR.

- Evaluation of surge and continuous irrigation( alterernative or irrigation of all furrows): was calculated according to equation described by James (1988) as follows:

$R z=D\left(\Theta_{F C}-\Theta_{I}\right) / 100=W a-D p-R o$

$\mathrm{Wa}=\mathrm{Qt} / \mathrm{A}$

Where:

$\mathrm{Rz}=$ Amount of water stored in the effective root zone $(\mathrm{m})$

$\mathrm{Wa}=$ Total water applied $(\mathrm{m})$

$\Theta_{\mathrm{FC}}$ and $\Theta_{\mathrm{I}}=$ Volumetric water contents in percent at field capacity and prior to irrigation, respectively.

$\mathrm{Q}=$ Average stream size during the irrigation $\left(\mathrm{m}^{3} / \mathrm{sec}\right.$.)

$\mathrm{T}=$ Duration of the irrigation (sec.)

$\mathrm{Dp}=$ Deep percolation $(\mathrm{m})$

Ro $=$ Run off $(\mathrm{m})$

$A=$ Area irrigated $\left(\mathrm{m}^{2}\right)$

$\mathrm{Ro}=\mathrm{Wa}-\mathrm{D}^{-}$where:

$D^{-}=$Calculated infiltrated depth

$\mathrm{Dz}=\Theta_{\mathrm{Fc}}-\Theta_{\mathrm{m}}$ where:

$\mathrm{Dz}=$ Depth to fill root zone $(\mathrm{m})$

$\Theta_{\mathrm{FC}}=$ Moisture percent at field capacity

$\Theta_{m}=$ Moisture percent before irrigation

$\mathrm{Dp}=\mathrm{D}^{-}-\mathrm{Dz}$

\section{RESULTS AND DISCUSSION}

Evaluation of post planting and third irrigation with surge flow irrigation, alternative furrow and continuous irrigation treatments for the two growing seasons are presented in Tables (2, 3, 4 and 5) and illustrated in figs (1, 2, 3 and 4).

The results showed that the amount of water applied was affected by the surge flow treatments in the post and third irrigation throughout growing season 2006 (Tables 2 and 3). The highest values of applied water depth are recorded under the continuous irrigation $(8.37$ and $8.79 \mathrm{~cm}$,for post and third irrigation, respectively). On the contrary, the lowest values $(6.11$ and $6.08 \mathrm{~cm})$ are recorded with surge flow (20 minutes on and 10 minutes off) for both, respectively. It is noticed that the amount of water applied with alternative furrow irrigation are 6.90 and $8.61 \mathrm{~cm}$, for both respectively.

In the case of growing season 2007 (Tables 4 and 5), the highest values of water applied in the post and third irrigation are recorded with the continuous irrigation ( 8.23 and $7.84 \mathrm{~cm}$, respectively), while the lowest value is obtained with the alternative irrigation $(5.64 \mathrm{~cm})$ in the post irrigation and $(6.37 \mathrm{~cm})$ under surge $(15 \mathrm{~min}$. on and $5 \mathrm{~min}$. off) in the third irrigation. 
El-Hadidi, E. M. et al.

Fig (1): Evaluation of post irrigation for different treatments during growing season 2006.
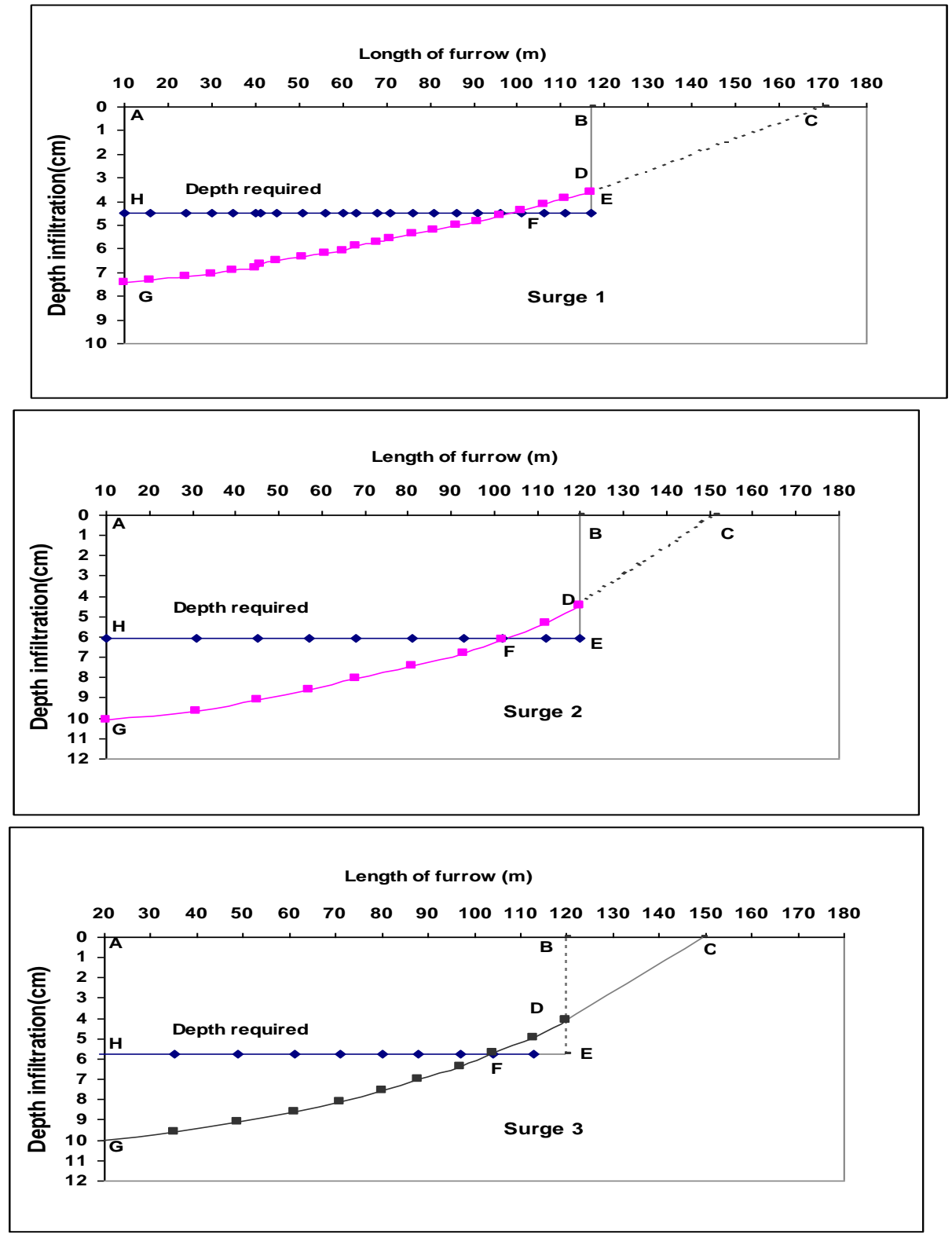
J. Agric. Sci. Mansoura Univ., 33 (7), July, 2008

Fig (1) Continues
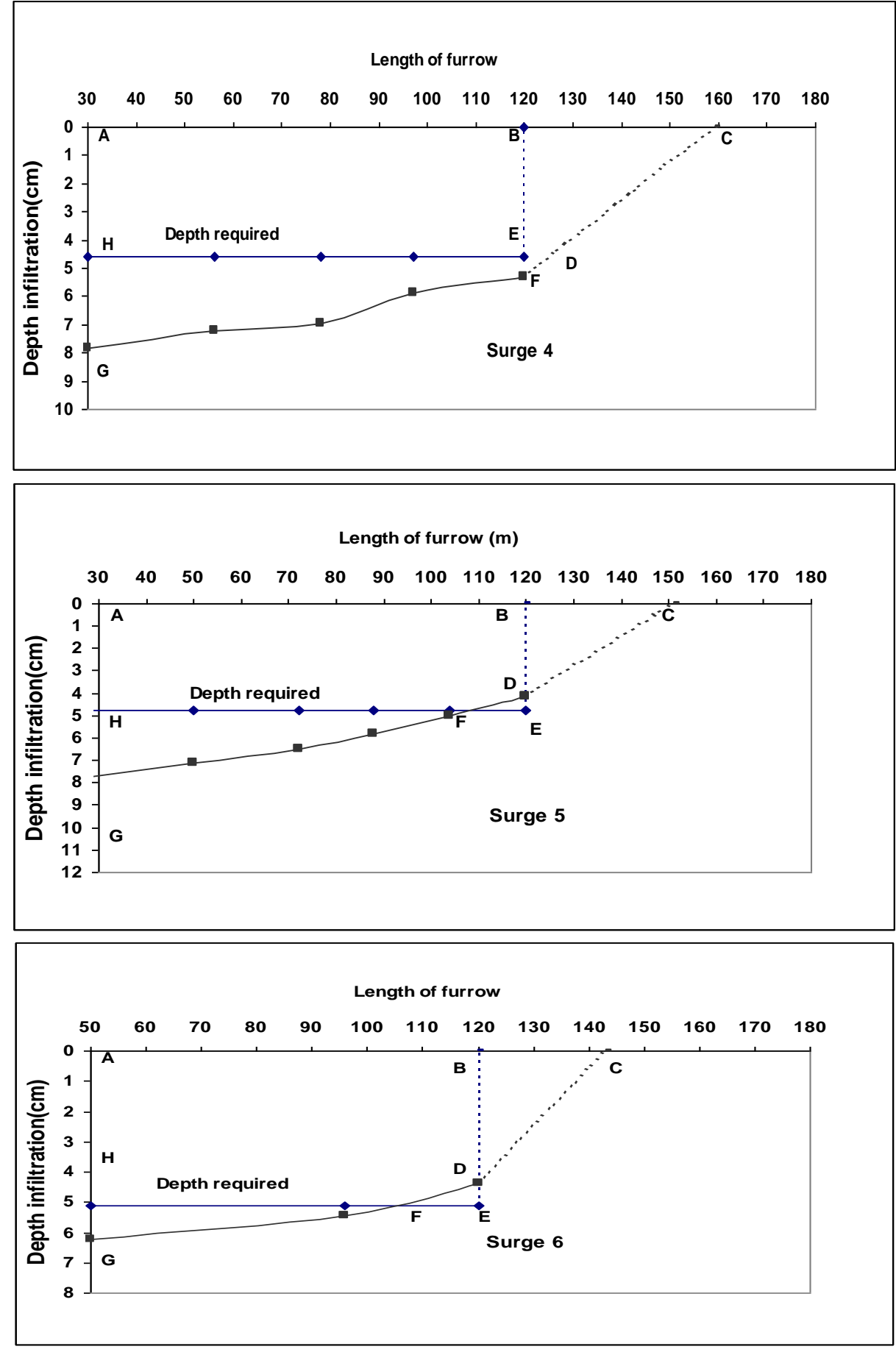

5433 
El-Hadidi, E. M. et al.

Fig (1) Continues
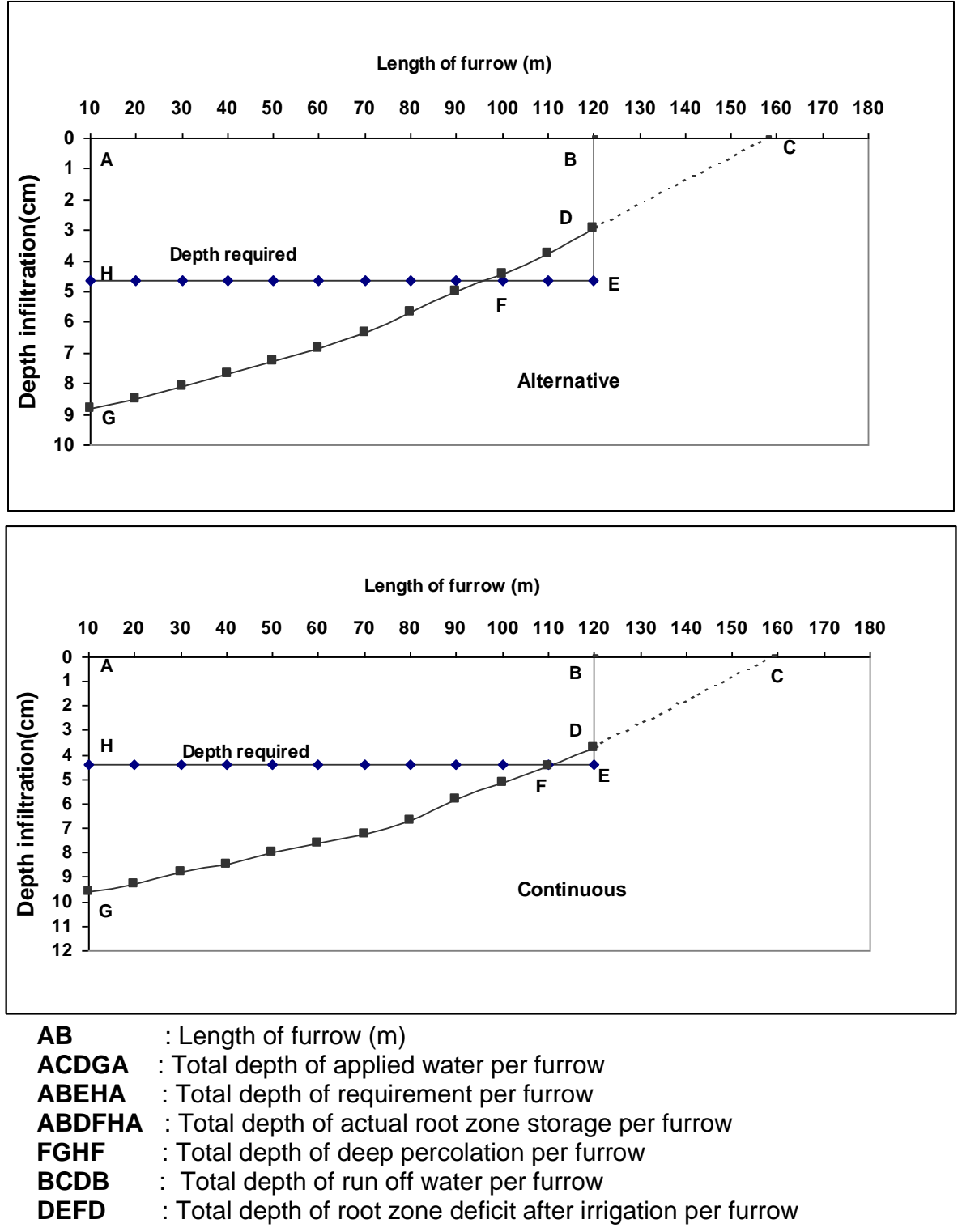

These data showed that the depth infiltrated is affected by the surge flow, alternative and continuous furrow irrigation with the post planting and third irrigation throughout growing season 2006 (Tables 2 and 3). The highest values are recorded under surge flow with $10 \mathrm{~min}$. on and $10 \mathrm{~min}$. off for the post planting $(6.73 \mathrm{~cm})$ and under alternative furrow with the third irrigation $(7.02 \mathrm{~cm})$. The lowest values are recoded under surge flow $15 \mathrm{~min}$. on and 5 min. off in the post planting $(5.13 \mathrm{~cm})$ and under surge flow $20 \mathrm{~min}$. on and 10 $\min$. off in the third irrigation $(4.78 \mathrm{~cm})$. 
Fig (2): Evaluation of third irrigation for different treatments during growing season 2006.
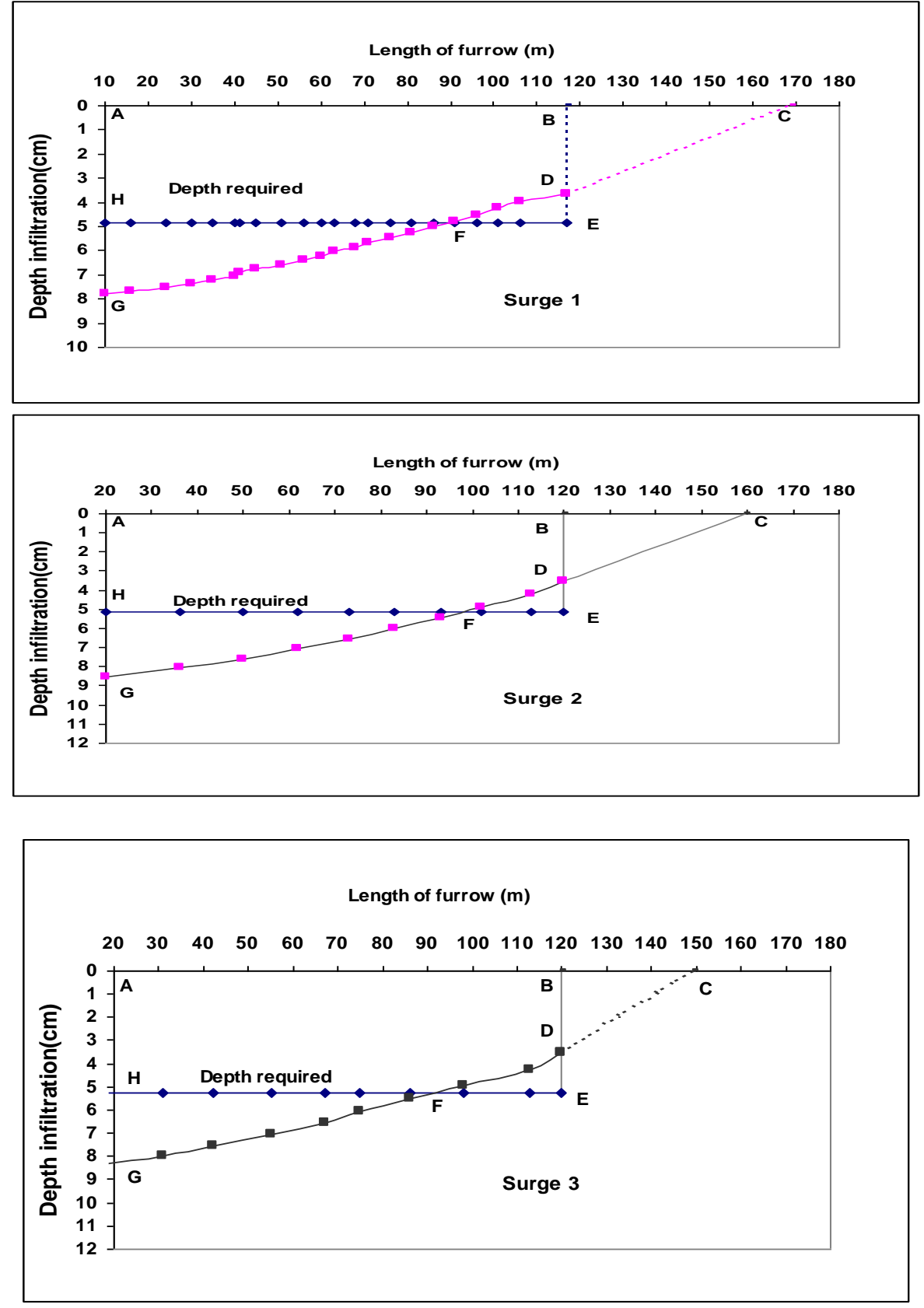
El-Hadidi, E. M. et al.

Fig (2) Continues
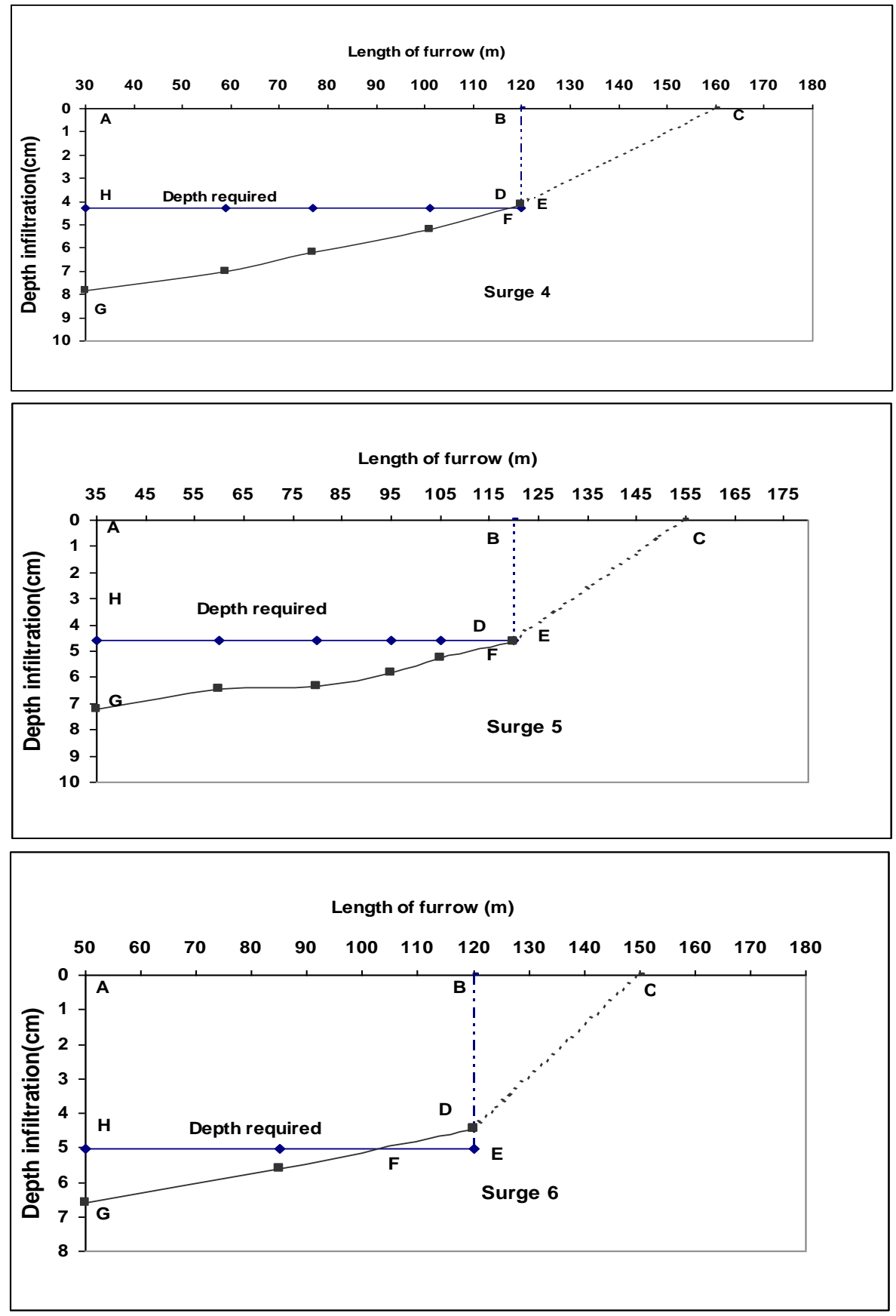


\section{Fig (2) Continues}
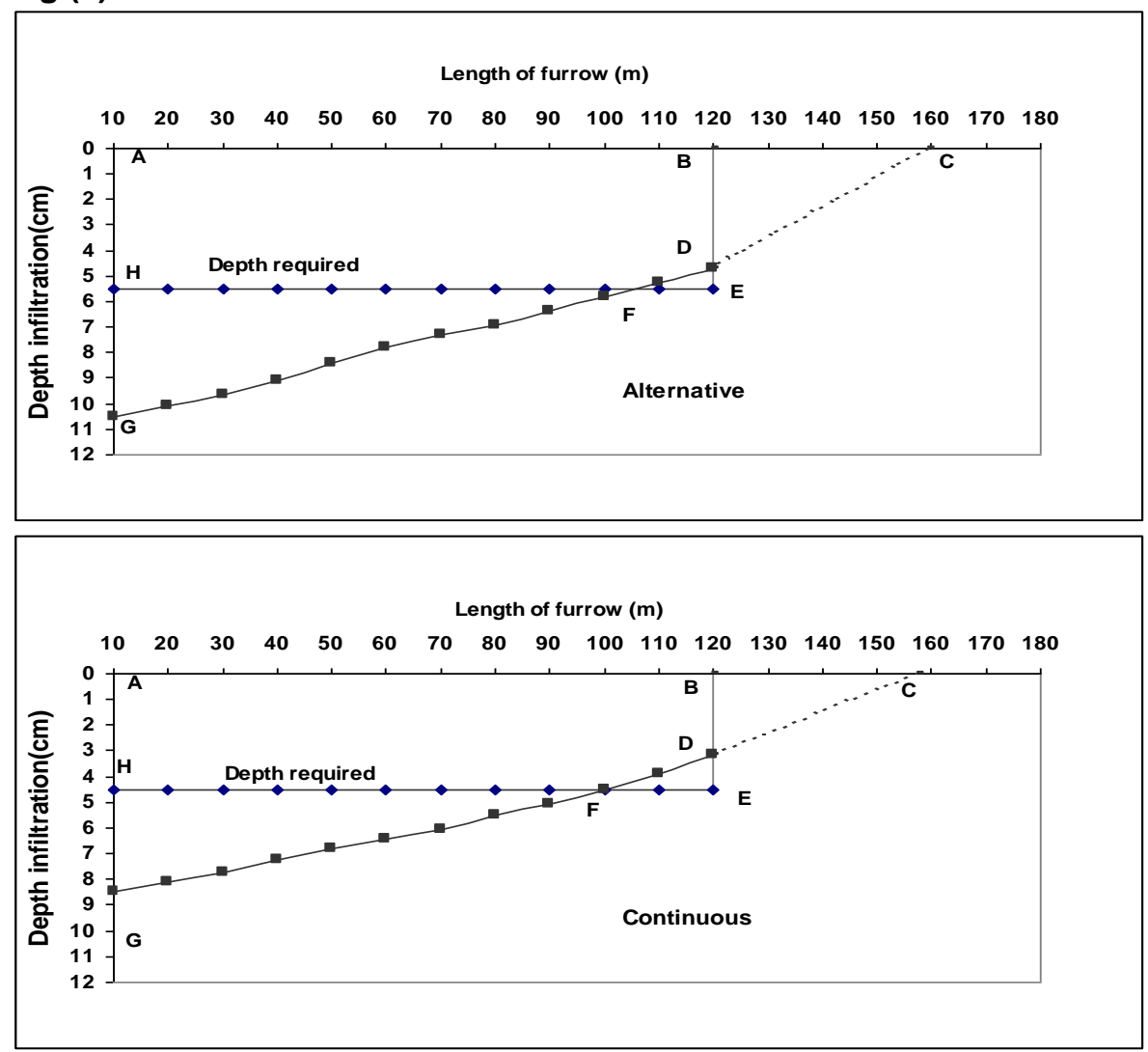

$A B$

: Length of furrow $(\mathrm{m})$

ACDGA : Total depth of applied water per furrow

ABEHA : Total depth of requirement per furrow

ABDFHA : Total depth of actual root zone storage per furrow

FGHF : Total depth of deep percolation per furrow

BCDB : Total depth of run off water per furrow

DEFD : Total depth of root zone deficit after irrigation per furrow

In the post and third irrigation growing season 2007 (Tables 4 and 5), the highest value of depth infiltrated $(6.81 \mathrm{~cm})$ is recorded with surge irrigation at 0.5 cycle ratio with post planting and $6.72 \mathrm{~cm}$ at 0.75 cycle ratio (surge 6). On the contrary the lowest values of infiltrated depth $(4.29$ and $5.18 \mathrm{~cm})$ are recorded with the alternative furrow irrigation with post planting irrigation and surge 5 with third irrigation, respectively. The infiltrated depth values under continuous flow are 6.09 and $5.65 \mathrm{~cm}$ were obtained with the post planting and third irrigation, respectively. 
El-Hadidi, E. M. et al.

Fig (3): Evaluation of post irrigation for different treatments during growing season 2007.
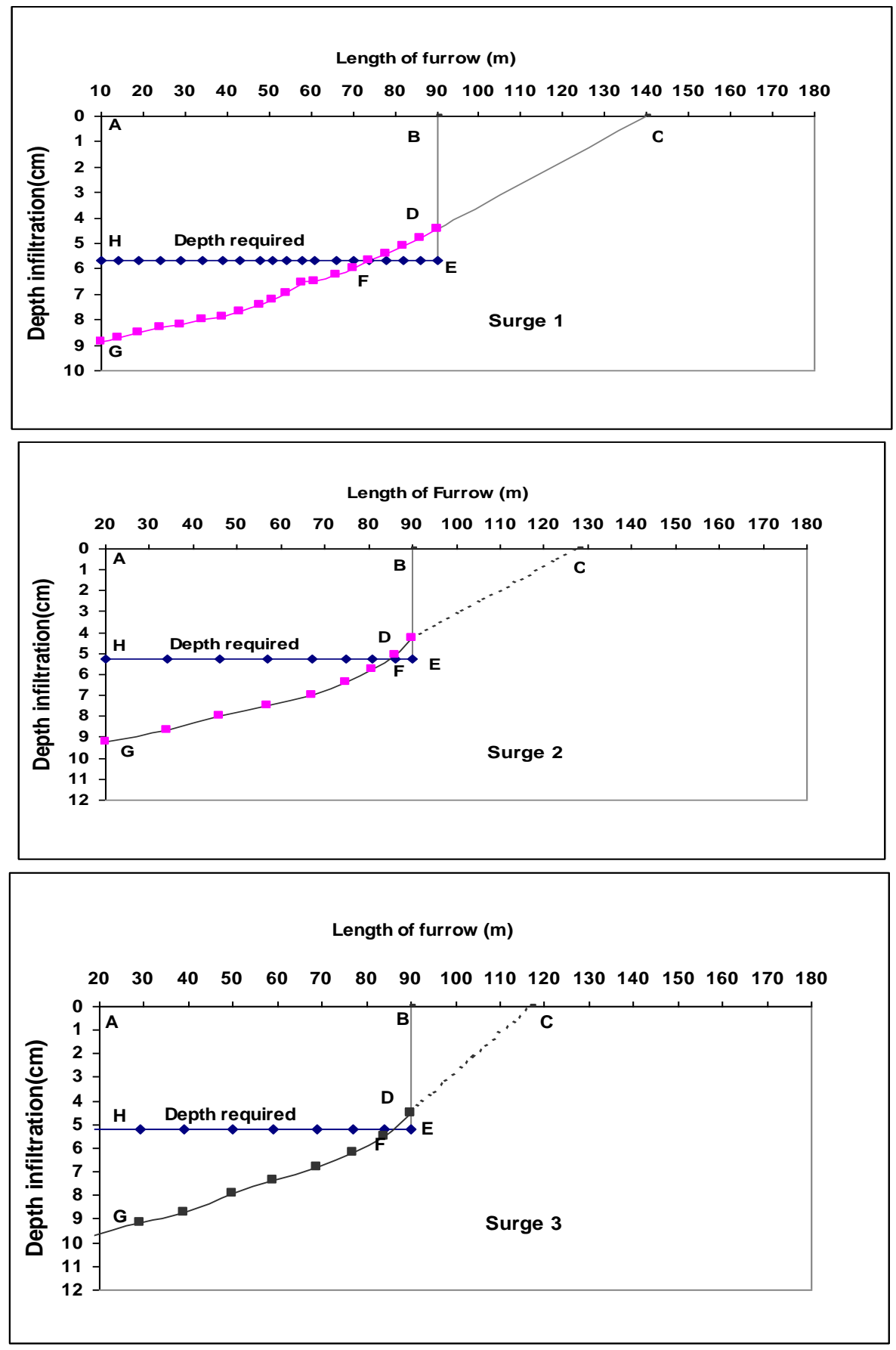
J. Agric. Sci. Mansoura Univ., 33 (7), July, 2008

Fig (3) Continues
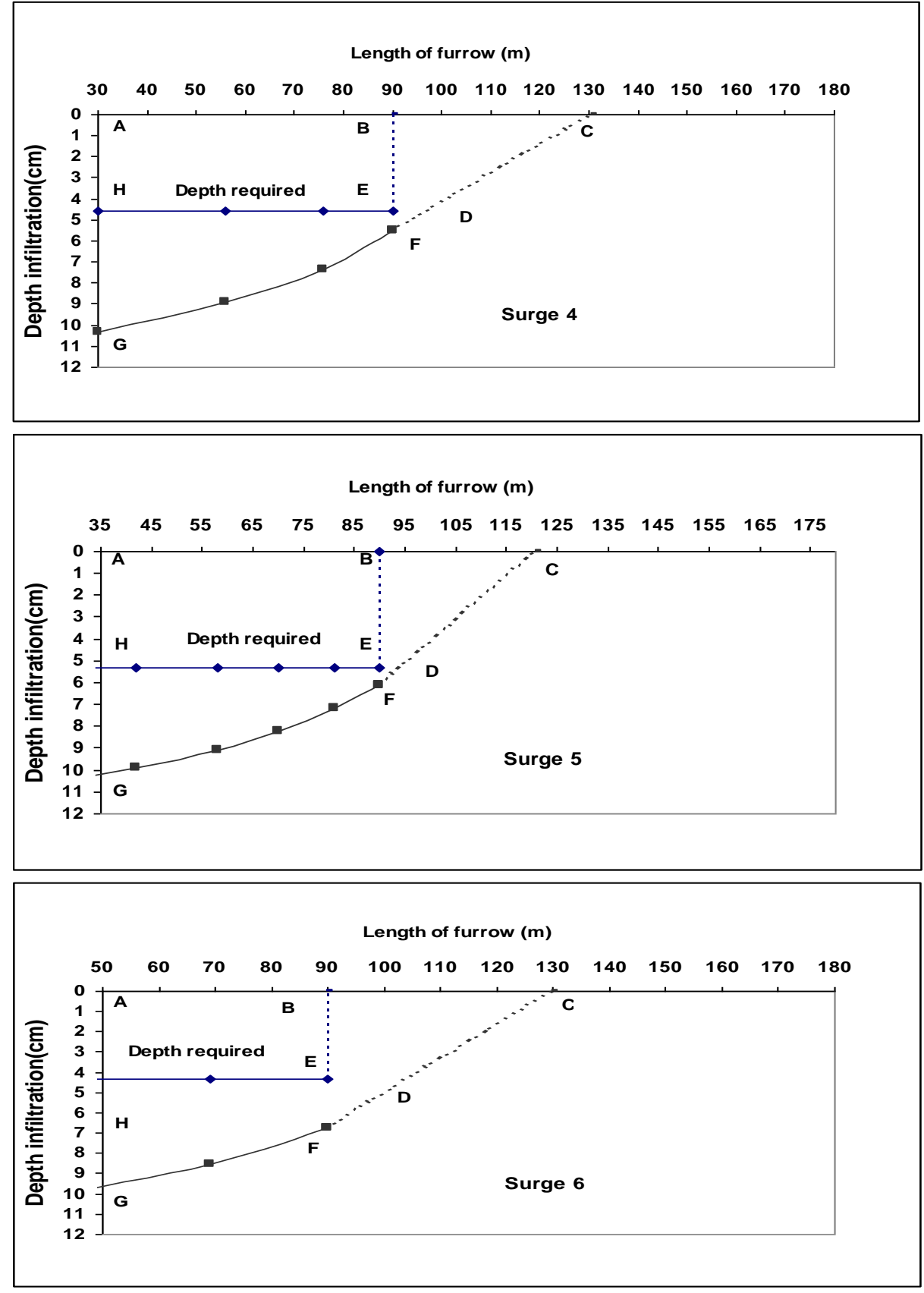
Fig (3) Continues

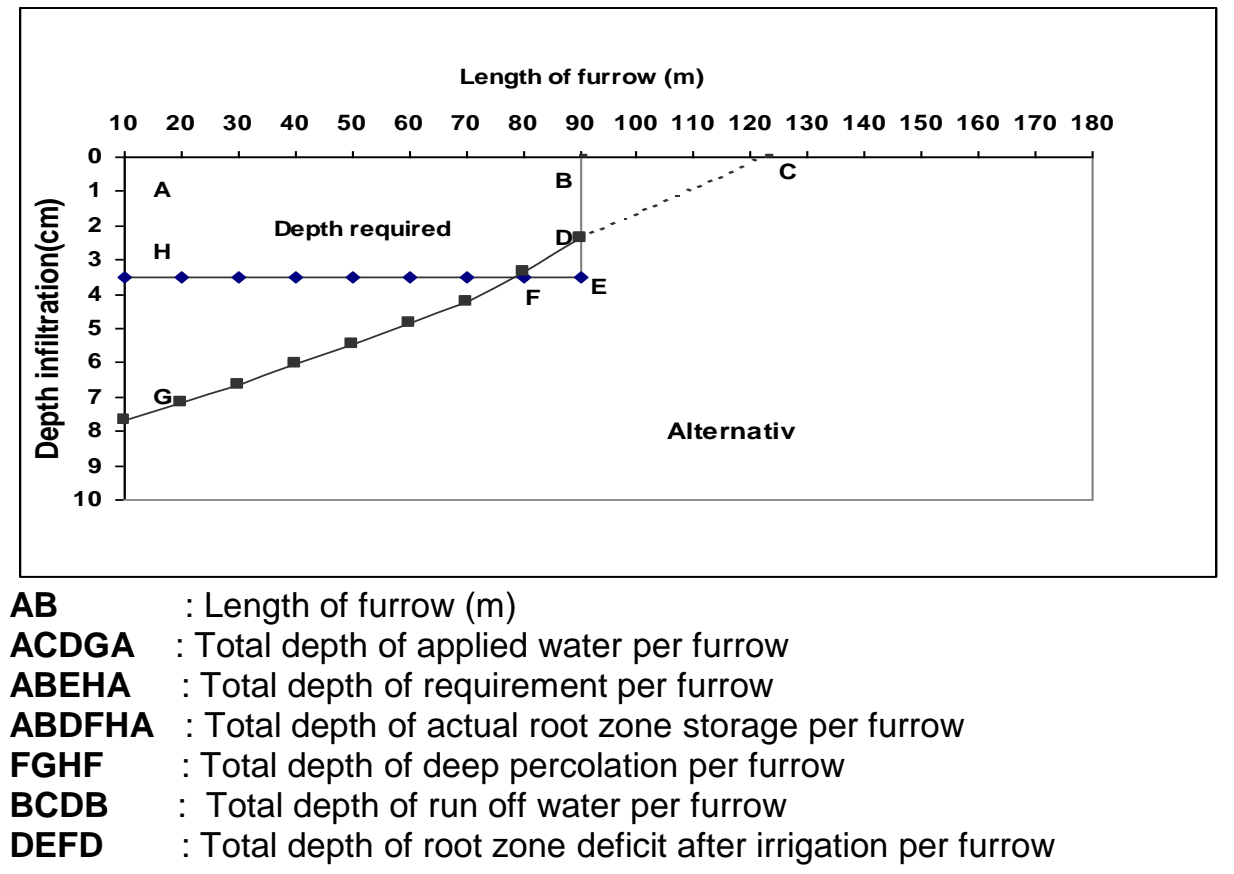

Table (2 to 5 ) showed that the run off depth is affected by different types of flow with post planting and third irrigation throughout growing season 2006 and 2007. In season 2006, the highest values of run off depth $(2.85$ and $3.19 \mathrm{~cm}$ ) are recorded under the continuous irrigation in the post planting and third irrigation, respectively, while, the lowest values of run off depth (0.59 and $0.94 \mathrm{~cm}$ ) are found with surge irrigation at 0.75 cycle ratio in the post planting and surge irrigation (Tables 2 and 3), respectively. The corresponding values $(1.12$ and $1.59 \mathrm{~cm})$ were obtained under alternative furrow irrigation with post planting and third irrigation, respectively.

In the season 2007 (Tables 4 and 5), the highest values of run off depth $(2.14$ and $2.19 \mathrm{~cm})$ are recorded under continuous irrigation with post planting and third irrigation, respectively while, the lowest values are recorded under surge flow at 0.66 cycle ratio in the post planting irrigation $(0.22 \mathrm{~cm})$ and with surge $6(0.64 \mathrm{~cm})$ in the third irrigation. It is observed that the run off depths $(1.35$ and $1.05 \mathrm{~cm})$ were obtained with alternative furrow irrigation in the post planting and surge irrigation, respectively. 
Fig (4): Evaluation of third irrigation for different treatments during growing season 2007.
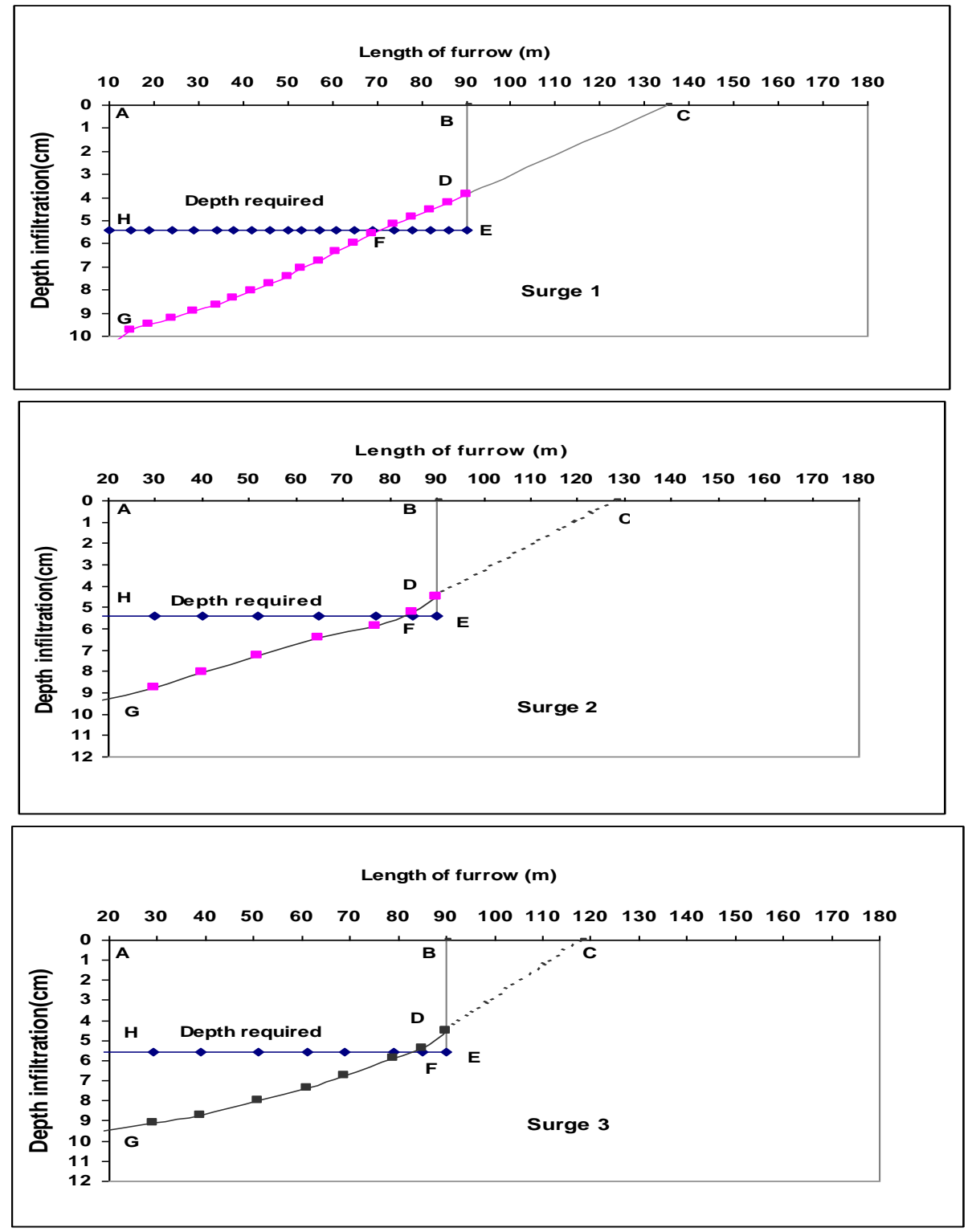
El-Hadidi, E. M. et al.

Fig (4) Continues
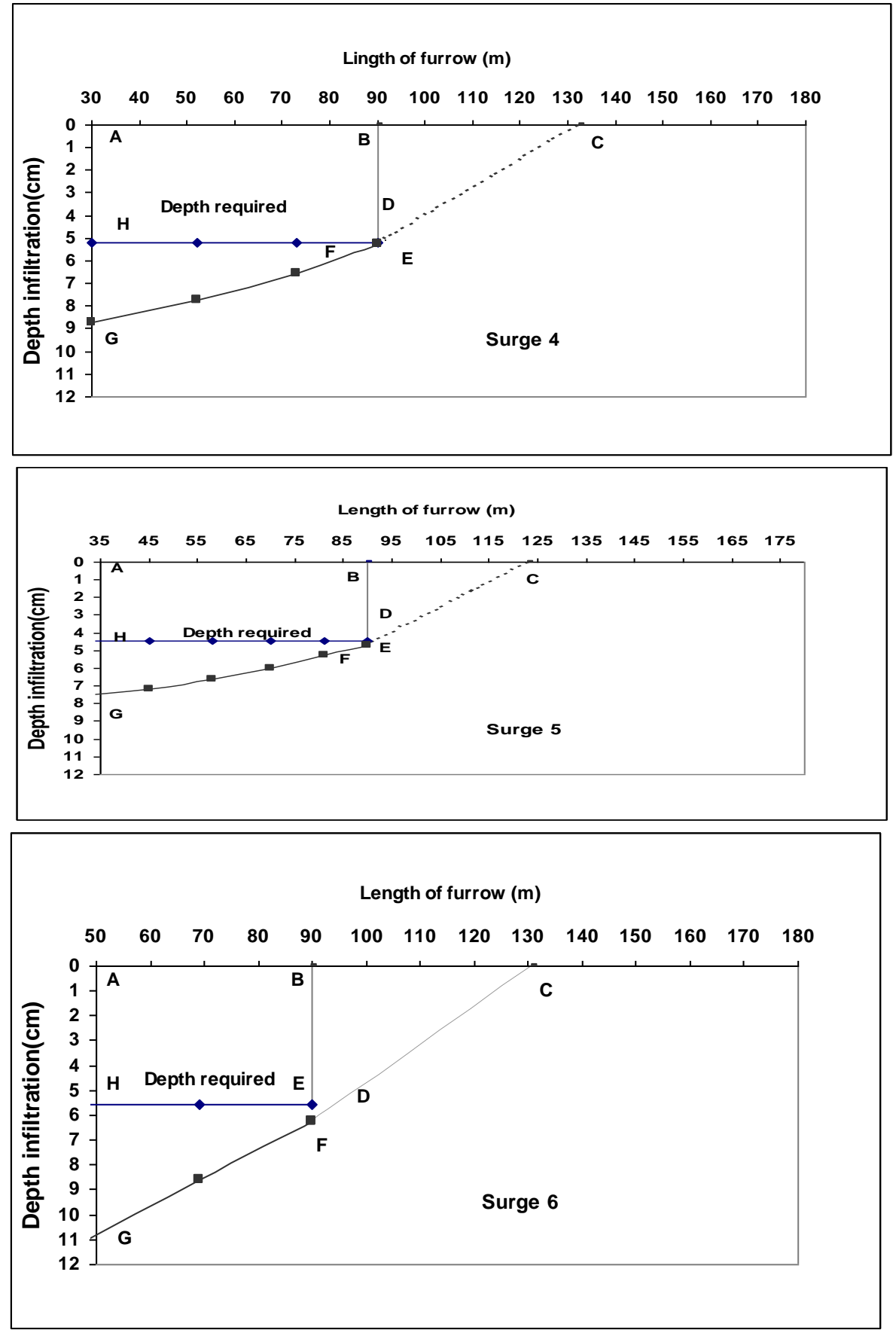
Fig (4) Continues
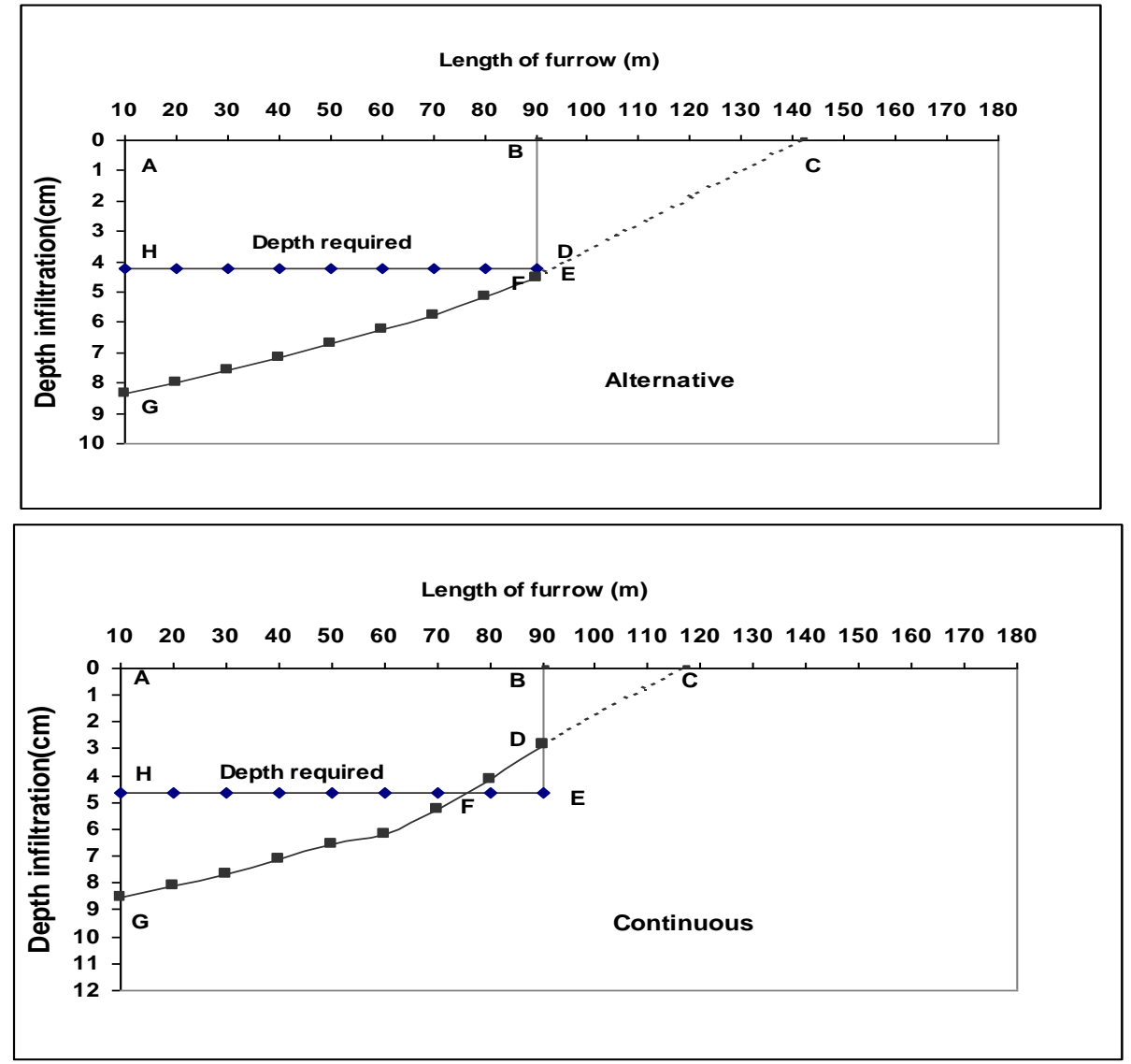
$A B$
: Length of furrow $(\mathrm{m})$
ACDGA : Total depth of applied water per furrow
ABEHA : Total depth of requirement per furrow
ABDFHA : Total depth of actual root zone storage per furrow
FGHF : Total depth of deep percolation per furrow
BCDB : Total depth of run off water per furrow
DEFD : Total depth of root zone deficit after irrigation per furrow

Tables (2 to 5) showed that the depth required to fill root zone at field capacity is affected by the surge flow, alternative furrow irrigation and continuous irrigation treatments in the post planting and third irrigation during growing seasons 2006 and 2007. The highest values in 2006 (Tables 2 and 3 ) are recorded under the surge with $10 \mathrm{~min}$. on and $10 \mathrm{~min}$. off in the post planting irrigation $(6.04 \mathrm{~cm})$ and with the alternative treatment in the third irrigation $(5.48 \mathrm{~cm})$, respectively while the lowest values are recorded under continuous irrigation treatment in the post planting irrigation $(4.37 \mathrm{~cm})$ and surge with $20 \mathrm{~min}$. on and $10 \mathrm{~min}$. off in the third irrigation $(4.28 \mathrm{~cm})$. 
In the growing season (2007) (Tables 4 and 5) the highest depths required to fill zone at field capacity are obtained under surge with $5 \mathrm{~min}$. on and 5 min. off in the post planting irrigation $(5.68 \mathrm{~cm})$ and with surge with $30 \mathrm{~min}$. on and $10 \mathrm{~min}$. off in the third irrigation $(5.58 \mathrm{~cm})$. On the contrary, the lowest values for depth required are found under the alternative furrow irrigation treatment $(3.35 \mathrm{~cm})$ in the post planting and in the third irrigation $(4.21 \mathrm{~cm})$.

It could be noticed that the depth required for the continuous irrigation are 4.96 and $4.62 \mathrm{~cm}$ in the post planting and third irrigation, respectively.

Table (2): Evaluation of post irrigation for different treatments, throughout growing season 2006

\begin{tabular}{|c|c|c|c|c|c|c|c|c|c|}
\hline \multirow{2}{*}{ Treatments } & \multicolumn{2}{|c|}{$\begin{array}{l}\text { Cycle } \\
\text { time } \\
\text { min. }\end{array}$} & \multirow{2}{*}{$\begin{array}{l}\text { Amount } \\
\text { of water } \\
\text { applied } \\
\text { (cm) }\end{array}$} & \multirow{2}{*}{$\begin{array}{l}\text { Depth } \\
\text { infiltrated } \\
(\mathrm{cm})\end{array}$} & \multirow{2}{*}{$\begin{array}{c}\text { Run } \\
\text { off } \\
\text { (cm) }\end{array}$} & \multirow{2}{*}{$\begin{array}{c}\text { Depth } \\
\text { to fill } \\
\text { root } \\
\text { zone } \\
\text { at F.C. } \\
\text { (cm) }\end{array}$} & \multirow{2}{*}{$\begin{array}{l}\text { Deep } \\
\text { percolation } \\
(\mathrm{cm})\end{array}$} & \multirow{2}{*}{$\begin{array}{c}\text { Water } \\
\text { application } \\
\text { efficiency } \\
\%\end{array}$} & \multirow{2}{*}{$\begin{array}{c}\text { Water } \\
\text { distribution } \\
\text { efficiency } \\
\%\end{array}$} \\
\hline & On & Off & & & & & & & \\
\hline Surge 1 & 5 & 5 & 6.93 & 5.58 & 1.35 & 4.47 & 1.11 & 64.50 & 83.30 \\
\hline Surge 2 & 10 & 10 & 7.64 & 6.73 & 0.91 & 6.04 & 0.69 & 79.06 & 80.00 \\
\hline Surge 3 & 10 & 5 & 7.48 & 6.57 & 0.91 & 5.74 & 0.83 & 76.74 & 78.40 \\
\hline Surge 4 & 20 & 10 & 6.11 & 5.27 & 0.84 & 4.58 & 0.99 & 70.0 & 87.47 \\
\hline Surge 5 & 15 & 5 & 6.30 & 5.13 & 1.17 & 4.76 & 0.37 & 75.60 & 82.56 \\
\hline Surge 6 & 30 & 10 & 6.18 & 5.59 & 0.59 & 5.10 & 0.49 & 82.52 & 87.60 \\
\hline Alternative & & & 6.90 & 5.78 & 1.12 & 4.62 & 1.16 & 66.96 & 74.40 \\
\hline \begin{tabular}{|l|} 
Continuous \\
\end{tabular} & & & 8.37 & 5.52 & 2.85 & 4.37 & 1.15 & 52.21 & 77.50 \\
\hline
\end{tabular}

Table (3): Evaluation of the third irrigation for the different treatments, throughout growing season 2006

\begin{tabular}{|c|c|c|c|c|c|c|c|c|c|}
\hline \multirow{2}{*}{ Treatments } & $\begin{array}{c}\text { Cycle } \\
\text { time } \\
\text { min. }\end{array}$ & On & $\begin{array}{c}\text { Amount } \\
\text { of water } \\
\text { applied } \\
\text { (cm) }\end{array}$ & $\begin{array}{c}\text { Depth } \\
\text { infiltrated } \\
\text { (cm }\end{array}$ & $\begin{array}{c}\text { Run } \\
\text { off } \\
\text { (cm) }\end{array}$ & $\begin{array}{c}\text { Depth } \\
\text { to fill } \\
\text { root } \\
\text { zone } \\
\text { at F.C. } \\
\text { (cm) }\end{array}$ & $\begin{array}{c}\text { Deep } \\
\text { percolation } \\
\text { (cm) }\end{array}$ & $\begin{array}{c}\text { Water } \\
\text { application } \\
\text { efficiency } \\
\%\end{array}$ & $\begin{array}{c}\text { Water } \\
\text { distibution } \\
\text { efficiency } \\
\%\end{array}$ \\
\hline Surge 1 & 5 & 5 & 6.96 & 5.68 & 1.26 & 4.83 & 0.85 & 69.60 & 82.50 \\
\hline Surge 2 & 10 & 10 & 6.69 & 5.69 & 1.00 & 5.15 & 0.54 & 76.98 & 78.00 \\
\hline Surge 3 & 10 & 5 & 7.15 & 5.62 & 1.53 & 5.25 & 0.40 & 73.00 & 82.30 \\
\hline Surge 4 & 20 & 10 & 6.08 & 4.78 & 1.30 & 4.28 & 0.50 & 70.40 & 81.40 \\
\hline Surge 5 & 15 & 5 & 6.17 & 4.92 & 1.25 & 4.60 & 0.32 & 74.60 & 82.21 \\
\hline Surge 6 & 30 & 10 & 6.62 & 5.68 & 0.94 & 5.02 & 0.66 & 75.83 & 86.20 \\
\hline Alternative & & & 8.61 & 7.02 & 1.59 & 5.48 & 1.54 & 63.65 & 79.10 \\
\hline Continuous & & & 8.79 & 5.60 & 3.19 & 4.51 & 1.09 & 51.30 & 77.30 \\
\hline
\end{tabular}

Tables (2 to 5) showed that the deep percolation is affected by the surge flow, alternative furrow irrigation and continuous irrigation treatments with the post planting and third irrigation during growing seasons (2006 and 2007). The highest values of deep percolation in 2006 (Tables 2 and 3) are recorded under the alternative treatment with the post planting and third irrigation (1.16 and $1.54 \mathrm{~cm}$, respectively). On the contrary, the lowest values of deep percolation are found under surge with $15 \mathrm{~min}$. on and $5 \mathrm{~min}$. off with the post planting and third irrigation (0.37 and $0.32 \mathrm{~cm}$, respectively) while, under 
continuous irrigation these values are 1.15 and $1.09 \mathrm{~cm}$ with the post planting and third irrigation, respectively.

In the post planting and third irrigation during growing season (2007), Tables 4 and 5 showed that the highest values of deep percolation are recorded under surge with $10 \mathrm{~min}$. on and $5 \mathrm{~min}$. off in the post planting irrigation $(1.36 \mathrm{~cm})$ and under alternative in the third irrigation $(1.68 \mathrm{~cm})$. It is noticed that the deep percolation values for the continuous irrigation in the post planting and third irrigation are 1.13 and $1.03 \mathrm{~cm}$, respectively. The higher values of deep percolation and runoff could be attributed to that the infiltrated depth is more than the required depth.

The results showed that the water application efficiency is clearly affected by the surge flow, alternative and continuous irrigation treatments in the post planting and third irrigation during both growing season. The highest value of water application efficiency in 2006 (Tables 2 and 3) was recorded under the surge irrigation with $30 \mathrm{~min}$. on and $10 \mathrm{~min}$. off (82.52\%) with the post planting irrigation, while the corresponding value $(76.98 \%)$ is obtained under the surge with $10 \mathrm{~min}$. on and $10 \mathrm{~min}$. off in third irrigation. In this case, overirrigation occurs over the whole length of the furrow. On the contrary, the lowest values are found under continuous irrigation treatments in the post planting and third irrigation (52.21 and $51.3 \%$, respectively). The values of water application efficiency for the alternative furrow in the post planting and third irrigation are 66.96 and $63.65 \%$, respectively.

In case of growing season (2007), the highest values of water application efficiency (Tables 4 and 5) are recorded under the surge irrigation with 10 min. on and $10 \mathrm{~min}$. off in the post planting and third irrigation (79.2 and $81.86 \%$, respectively) while the lowest values are obtained with the continuous in the post planting and third irrigation $(60.3$ and $58.93 \%$, respectively). It is noticed that the water application efficiency for the alternative furrow are 62.6 and $60.66 \%$ in the post planting and third irrigation, respectively.

Tables 2-5 showed that the values of water distribution efficiency are affected by the surge flow, alternative and continuous treatments. The highest values in 2006 season (Tables 2 and 3) are recorded under the surge with $30 \mathrm{~min}$. on and $10 \mathrm{~min}$. off in the post planting and third irrigation (87.6 and $86.2 \%$, respectively). The lowest values are recorded under alternative in the post planting $(74.4 \%)$ and under continuous irrigation in the third irrigation (77.3\%).

During growing season (2007), the highest values of water distribution efficiency (Tables 4 and 5) are achieved under surge with $30 \mathrm{~min}$. on and 10 min. off for post planting irrigation (86\%) and under surge irrigation with 15 min. on and $5 \mathrm{~min}$. off in the third irrigation (85.31\%). On the contrary, the lowest values of the water distribution efficiency are obtained with the alternative treatments in the post planting irrigation (73.9\%) and under surge irrigation with $5 \mathrm{~min}$. on and $5 \mathrm{~min}$. off with the third irrigation $(76.42 \%)$.

These findinges are in a good agreement with those obtained by Ghalleb (1987), Osman (1991), Osman et al. (1996), Eid (1998) and Aiad (2003). 
Table (4): Evaluation of post planting irrigation for different treatments, throughout growing season 2007

\begin{tabular}{|c|c|c|c|c|c|c|c|c|c|}
\hline \multirow[b]{2}{*}{ Treatn } & \multicolumn{2}{|c|}{\begin{tabular}{|l} 
Cycle \\
time \\
min. \\
\end{tabular}} & \multirow{2}{*}{ 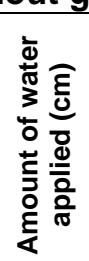 } & \multirow{2}{*}{ 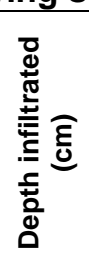 } & \multirow{2}{*}{ 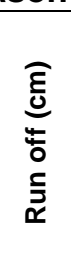 } & \multirow{2}{*}{ 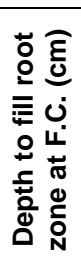 } & \multirow{2}{*}{ 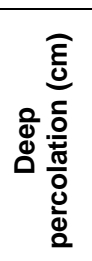 } & \multirow{2}{*}{ 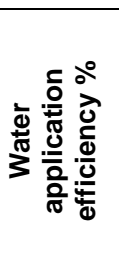 } & \multirow{2}{*}{ 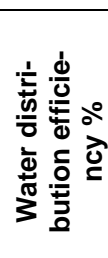 } \\
\hline & On & Off & & & & & & & \\
\hline Surge 1 & 5 & 5 & 7.74 & 6.81 & 0.93 & 5.68 & 1.13 & 73.40 & 83.20 \\
\hline Surge 2 & 10 & 10 & 6.62 & 5.76 & 0.86 & 5.24 & 0.52 & 79.20 & 80.60 \\
\hline Surge 3 & 10 & 5 & 6 & 6.56 & 0.22 & 5. & 1.36 & 76.70 & 80.70 \\
\hline Surge 4 & 20 & 10 & 6.22 & 5.37 & 0.85 & 4.56 & 0.81 & 73.30 & 80.20 \\
\hline Surge 5 & 15 & 5 & 7.20 & 6.51 & 0.69 & 5.30 & 1.21 & 73.61 & 84.10 \\
\hline Surge 6 & 30 & 10 & 6.11 & 5.14 & 0.96 & 4.3 & 0.83 & 70.70 & 86.00 \\
\hline \begin{tabular}{|l|} 
Alternative \\
\end{tabular} & & & 5.64 & 4.29 & 1.35 & 3.53 & 0.76 & 62.60 & 73.90 \\
\hline \begin{tabular}{|l|} 
Continuous \\
\end{tabular} & & & 8.23 & 6.09 & 2.14 & 4.96 & 1.13 & 60.30 & 74.40 \\
\hline
\end{tabular}

Table (5): Evaluation of the third irrigation for the different treatments, throughout growing season 2007

\begin{tabular}{|c|c|c|c|c|c|c|c|c|c|}
\hline \multirow{2}{*}{ Treatments } & \multicolumn{2}{|c|}{$\begin{array}{l}\text { Cycle } \\
\text { time } \\
\text { min. }\end{array}$} & \multirow{2}{*}{ 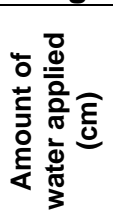 } & \multirow{2}{*}{ 동 } & \multirow{2}{*}{ 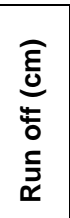 } & \multirow{2}{*}{ 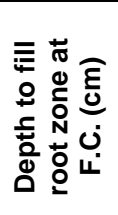 } & \multirow{2}{*}{ 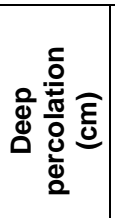 } & \multirow{2}{*}{ 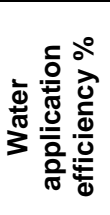 } & \multirow{2}{*}{ 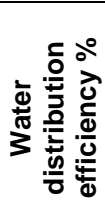 } \\
\hline & On & Off & & & & & & & \\
\hline Surge 1 & 5 & 5 & 7.74 & 6.59 & 1.15 & 5.41 & 1.18 & 69.90 & 76.42 \\
\hline Surge 2 & 10 & 10 & 6.56 & 5.83 & 0.73 & 5.37 & 0.46 & 81.86 & 80.00 \\
\hline Surge 3 & 10 & 5 & 7.41 & 6.38 & 1.03 & 5.55 & 0.83 & 74.89 & 80.10 \\
\hline Surge 4 & 20 & 10 & 6.83 & 5.86 & 0.97 & 5.19 & 0.67 & 75.99 & 83.34 \\
\hline Surge 5 & 15 & 5 & 6.37 & 5.18 & 1.19 & 4.46 & 0.72 & 70.02 & 85.31 \\
\hline Surge 6 & 30 & 10 & 7.36 & 6.72 & 0.64 & 5.58 & 1.14 & 75.82 & 80.00 \\
\hline Alternative & & & 6.94 & 5.89 & 1.05 & 4.21 & 1.68 & 60.66 & 81.30 \\
\hline Continuous & & & 7.84 & 5.65 & 2.19 & 4.62 & 1.03 & 58.93 & 76.57 \\
\hline
\end{tabular}

\section{Conclusions:}

It can be concluded that the performance of the system during the evaluation is acceptable in case of surge irrigation with $10 \mathrm{~min}$. on and 10 min. off or $30 \mathrm{~min}$. on and $10 \mathrm{~min}$. off treatments in the two growing seasons. In case of continuous flow, the performance of the system is inefficient since about 48 percent of the water applied was lost from the field as runoff or deep percolation.

\section{REFERENCES}

Aiad, M. A. El. (2003). Effect of surge irrigation on water conceptive use and nutrients uptake of cotton. M.Sc. Thesis Soil scie., Fac. Agric., Mansoura University

Allen, N. L. (1980). Advance rates in furrow irrigation for cycled flow, Thesis presented to the Utah State University at Logan, Utah, M.SC. Degree, U.S.A.

Bishop, A. A.; W. R. Walker; L. N. Allen and J. Poole (1981). Furrow advance rates under surge flow system. J. Irrigation and Drainage, Division ASCE, 107: 257-264. 
Black, C. A. (1965). Methods of Soil Analysis, Part I. Am. Soc. Agron., Madison Wisconson. U.S.A.

Eid, S. M. (1998). Surge flow irrigation for corn and wheat under different land leveling practices in heavy clay soil ph. D. Thesis, Fac. Agric., Tanta Univ. Egypt.

El-Shahawy, M. I. (2004). Some aspects of water management in furrow irrigation under cotton crop. J. Agric. Sci. Mansoura Univ. Egypt, 29(6): $3651-3660$.

Garcia, G. (1978). Soil Water Engineering Laboratory Manual. Colorado State Univ., Dept. of Agric. and Chemical Engineering. Fortcollins, Colorado, USA.

Ghalleb, A. A. (1987). Evaluation of surge irrigation for different field crops. Ph. D. Thesis, Fac. Agric., Alex. Univ. Egypt.

Ismail, S. M.; G. L. Westesen and W.E. Larsen. (1985). Surge flow border irrigation using an automatic drop gate. Transaction of the A.S.A.E, 28, No. 2.

James, L.G. (1988). " Principles of farm irrigation system design" John willey \& Sons (ed.), New York, PP. 543.

Meleha, M. E. (2000). Effect of furrow length and methods of applying irrigation water on cotton yield and water use efficiency. J. Agric. Sci. Mansoura Univ. 25: 3883-3890.

Merriam, J. L. and Keller, U. (1978). Farm irrigation system evaluation: A guide for management. Agricultural and irrigation Engineering department, Utah state Univ. Logan Utah, 271 p.

Osman, A. M.; M.M. Attia; H. El-Zaher and M. A. Sayed (1996). Surge flow furrow irrigation in calcareous soil. 1. Furrow advance time function and applied water. J. Agric. Sci. Mansoura Univ. Egypt, 21(10): 3671-3678.

Osman, A.M. (1991). Surge flow irrigation for corn and faba bean in clay soil. Ph. D. Thesis, Soil Sci., Fac. Agric., Alex. Univ. Egypt.

Stringham, G. E. and J. Keller (1979). Surge flow for automatic irrigation, ASEC Irrigation and Drainage Division, Special Conference Held at Albuquerque, New Mexico, presented at July. pp. 132-142.

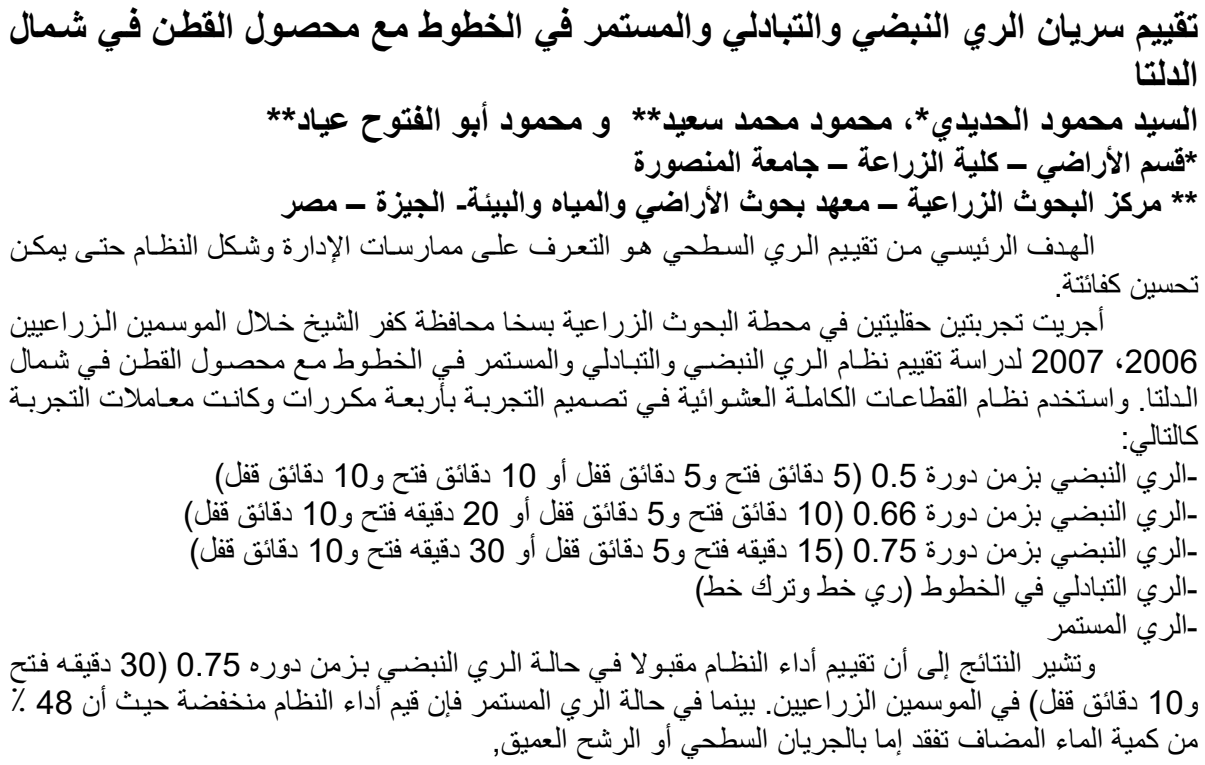

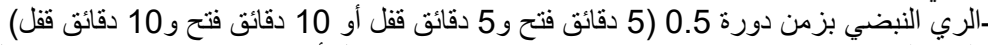

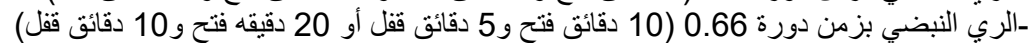

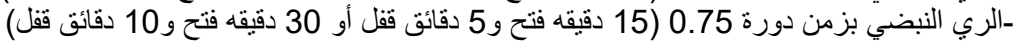
ـالري التبادلي في الخطوط (ري خط دون الرئرك خط

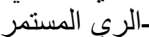

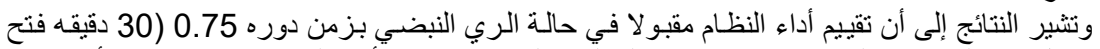

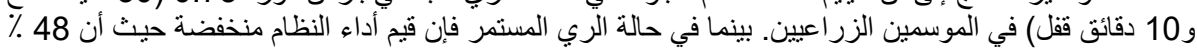

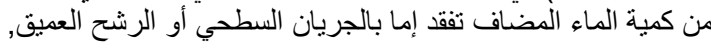

